\title{
Bride-kelin: ritual codex of traditional wedding rituals of the Sayan-Altai turks
}

\author{
DOI: $10.31551 / 2410-2725-2019-5-3-337-350$
}

\section{Tadysheva Natalya Olegovna}

candidate of Historical Sciences, Deputy Director of BNU RA "Scientific and Research Institute of Altaian Studies" n.a. S.S. Surazakov, Russian Federation, Altai Republic, Gorno-Altaisk. E-mail: tadisheva@mail.ru

\begin{abstract}
The article reveals the common elements of the traditional wedding rites of the Altaians, Khakas, Tuvinians, based on the binary opposition of "friend or foe" in relation to the bride-kelin. In the course of the wedding ceremony, the former social and kinship relations are reconstructed, first of all, in respect of the bride. As a result of the appropriate rituals, there is a "separation" of the girl from her family of parents, from the former home of the cult and her gradual inclusion into the new environment. Initially, the bride-kelin appears as a "stranger", "alien." Her "dangerous" influence against her new relatives is strong and measures of magical and religious protection are taken against her. There preserved an idea of the magical meaning of the word, when pronounced by some "alien", in this case, by an alien kelin, can be dangerous for the husband and his relatives and can cause them harm.

The same moments of the wedding ceremony of the Altaians, Tuvinians and Khakas were revealed, which were influenced by the binary opposition «friend or foe» in relation to the daughter-in-law; in particular, closing the bride's face with a wedding curtain, handkerchief, limiting contact with her before the rites of passage - she was accompanied the groom's nephews, Askak-Kadai, braiding bride's hair, giving a bowl with milk, the custom of avoiding the older relatives of the bride, whom the daughter-in law is following. There is also drawn the attention to the stable elements, which are evidenced by the oral folklore, in the article are examples from the heroic epos of the Altaians, Tuvinians and Khakas.

On the one hand, the wedding rituals in present conditions suffer transformations in the direction of simplification in urban settings; on the other hand, the holding of traditional weddings in museums and club institutions of Tuva and Khakassia indicates the popularization of traditional wedding ceremonies, where the attempt is made to save traditional culture. However, in these conditions, the considered materials evidence about saving of ideas about the daughter-in-law in the traditional picture of the world of the Turks of Sayan-Altai.
\end{abstract}

Keywords: wedding ritual; binary opposition "kin"-"alien"; sacredness; transition rites; variability; resistance; daughter-in-law 'kelin'; Altaians; Tuvinians; Khakas.

\section{Қалыңдық-келін: Саян-Алтай түркілерінің дәстүрлі той әдет-ғұрыптарының ритуалды коды}

\section{Тадышева Наталья Олеговна}

Тарих ғылымдарының кандидаты, "С.С. Суразаков атындағы алтаистика ҒЗИ" АР БҒМ директорының орынбасары, Ресей Федерациясы, Алтай Республикасы, Горно-Алтайск қ. E-mail: tadisheva@mail.ru

Аңдатпа. Мақалада қалыңдық-келінге қатысты "өзіндік - бөтен" екі жақты позицияға негізделген алтайлықтардың, тувалықтардың және хакастардың анықталған үйлену рәсімдерінің ортақ элементтері анықталған. Үйлену рәсімі үрдісі барысында бірінші кезекте қалыңдықтың қазіргі әлеуметтік-туысқандық қатынастары айқындалады. Осыған сәйкес жүргізілген әдет-ғұрыптардың соңында қызды ата - анасынан "алшақтату" жүргізіліп, бұрынғы ошақ ғұрпынан біртіндеп жаңа ортаға бейімдейді. Алғашында қалыңдық-келін "бөтен", "келген" адам ретінде есептеледі. Оның жаңа туыстарына ықпалы "қауіпті", сондықтан оған қарсы сиқырлы - діни қорғау шаралары қолданылады. "Бөтеннің" сөзінің сиқырлық мәні туралы түсінік сақталған, сондықтан, мұндай жағдайда бөтен рулы келін күйеуі мен оның туысқандарына қауіпті және оларға зиян тигізуі мүмкін.

Қалыңдыққа қатысты "өзіндік - бөтен" екі жақты позицияға негізделген алтайлықтардың, тувалықтардың және хакастардың анықталған үйлену рәсімдерінің барлық элементтері айқындалған, атап айтқанда келіннің бетін той пердесімен, орамалмен жауып, жаңа туысқандары жағына толық өту рәсімі өткенше, күйеу жігіттің нереме бауырлары келіннің жанында жүреді. Аскак - Қадай, шашты өру, сүт құйылған кесе әкелу, күйеудің жасы үлкен туысқандарына жақындамау сияқты рәсімдер жүргізіледі.

Сонымен қатар, халық ауыз фольклоры дәлелдейтін тұрақты элементтерге назар аударылған. Сондықтан, мақалада алтайлықтардың, тувалықтар мен хакастардың батырлық жырларынан мысалдар келтірілген. 
Қазіргі кезеңде үйлену рәсімдері бір жағынан қала жағдайында қарапайымдана түскен, екінші жағынан, Тува мен Хакасияда мұражайлар мен клубтық мекемелерде дәстүрл үйлену рәсімдерін өткізу дәстүрлі үйлену рәсімдерін жаңғырту және дәстүрлі мәдениетте сақтауға талпыныс жасауы ретінде қабылдау қажет. Бірақ, қарастырылып отырған материал осы жағдайлардың өзінде Саян-Алтай түріктерінің дәстүрлі әлемінде қалыңдық туралы көріністің сақталғандығын көрсетеді.

Түйін сөздер: үйлену рәсімділігі; "өзіндік - бөтен" екі жақты позиция; сакральды; өту рәсімдері; қалыңдық - келін; алтайлықтар; тувалықтар; хакастар.

\title{
Невестка-келин: ритуальный код традиционной свадебной обрядности тюрков Саяно-Алтая*
}

\section{Тадышева Наталья Олеговна}

кандидат исторических наук, заместитель директора БНУ РА «НИИ алтаистики им. С.С. Суразакова», Российская Федерация, Республика Алтай, Горно-Алтайск. E-mail: tadisheva@mail.ru

Аннотация. В статье выявляются общие элементы традиционной свадебной обрядности алтайцев, хакасов, тувинцев, основанные на бинарной оппозиции «свой - чужой» по отношению к невестке-келин. В процессе свадебного обряда перестраиваются прежние социальнородственные отношения, в первую очередь, невесты. В результате совершения соответствующих обрядов происходило «отделение» девушки от семьи родителей, от прежнего домашнего культа и постепенное включение в новую среду. Первоначально невеста келин предстает в качестве «чужой», «пришедшей». Ее «опасное» воздействие сильно по отношению к новым родственникам и против нее принимаются меры магически-религиозной защиты. Сохраняется представление о магическом значении слова, которое при произношении «чужим», в данном случае, чужеродной келин может быть опасным для мужа и его родственников и способно причинить им вред.

Раскрыты всевозможные моменты проведения свадебной церемонии у алтайцев, тувинцев и хакасов, на которые повлияли представления бинарной оппозиции «свой - чужой» по отношению к невестке, в частности, закрывание лица невесты свадебной занавесью, платком, ограничение контактов с ней до проведения обрядов перехода - ее сопровождают племянники жениха, Аскак-Кадай, заплетание волос, преподнесение пиалы с молоком, обычай избегания по отношению к старшим родственникам мужа, которого придерживается невестка. Также обращается внимание на устойчивые элементы, о которых свидетельствует устный народный фольклор, в статье приведены примеры из героического эпоса алтайцев, тувинцев и хакасов.

В современных условиях свадебная обрядность претерпевает трансформации с одной стороны в городских условиях в сторону упрощения, с другой стороны, проведение традиционных свадеб в музеях, клубных учреждениях в Туве и Хакасии свидетельствует о популяризации традиционных свадебных обрядов и предпринимается попытка сохранения традиционной культуры. Но и в этих условиях рассмотренный материал свидетельствует о сохранении представлений о невестке в традиционной картине мира тюрков Саяно-Алтая.

Ключевые слова: свадебная обрядность; бинарная оппозиция «свой» - «чужой»; сакральность; обряды перехода; изменчивость; устойчивость; невестка-келин; алтайцы; тувинцы; хакасы.

\section{UDC/УДК 39}

\section{Bride-kelin: ritual codex of traditional wedding rituals of the Sayan-Altai turks}

\author{
N.O. Tadysheva
}

Relevance. Introduction. Today in the context of globalization the transformation processes of traditional culture constitute the main content of ethno-

Публикация подготовлена в рамках выполнения проекта «История и культура Великой Степи», № $Ф .0832 / П Ф Ц$. 
cultural changes that have affected many nations. The response to the unification of ethnic cultures is the desire of peoples to preserve their traditional values, which is reflected in the strengthening of their national identity, in an effort not only to maintain but also to actualize traditional culture. Actualization of scientific and public attention to the national traditional culture is logical. Rituals related to the life cycle are important components of the traditional culture of each nation, and the issue of preserving the traditional becomes very important. Taking into consideration that the traditions of the past are transformed quite quickly in the modern world, their study becomes more and more relevant every year.

Materials and methods. To obtain analytical conclusions in this work both general scientific methods (analysis and synthesis) and descriptive method were used. The analysis of the material was made on the basis of the principle of historicism. In order to conduct a component analysis of the wedding rituals of the Turks of the Sayan-Altai area, a comparative ethnographic method was used. Therefore, materials, both published in the research literature and field materials of the author, were involved. The historical-genetic method made it possible to trace the evolution of their family rituals. To collect material on the topic of this work, the author purposefully conducted field research among the representatives of the Altai and Khakass people. The method of the included observation was used, as well as photo and video recordings were made. The interviewing method was also used as one of the main ethnographic methods of collecting information.

Discussions. The analysis of the role and place of the bride in the wedding rituals of the Altaians, Khakas and Tuvinians was carried out on the basis of materials from ethnographic literature of the late 19th - early 21 st century, as well as archival materials. In the historical and ethnographic literature since the XIX century. Attention was paid to the description of the traditional wedding rites. Chronologically, the first mention of the details of the wedding rites of the Türks is the work of G.F. Miller "Description of Siberian Peoples" (Miller 2009). Works of G.I. Spassky "Journey to the Altaian Kalmyks" (Spassky, 1819), A.M. Gorokhova "A brief ethnographic description of the Biysk or Altai Kalmyks" (Gorokhov, 1840), is the first information about the culture of the Altai, Tuvinians and Khakas. However, in the first half of the nineteenth century materials were not sufficient In the second half of the XIX century. Scientists and researchers presented only the most general information about beliefs, customs. V.V. Radlov, who visited South Siberia in the 60s.of the XIX century and summarized the results of his research in a book called "From Siberia" (Radlov 1989).

N. Kostrov's work "Women of Tomsk Province Aboriginals" also contains valuable information about wedding ceremonies, he described them as "very entertaining and breathing a kind of poetry" (Kostrov, 1875: 36).

G.N. Potanin collected and published folklore and ethnographic materials in "Sketches of North-Western Mongolia", which contains information about the family life of the Altai, Teleut and Uryankhai people (Potanin, 1883). N.F. Katanov made an invaluable contribution to the cause of preservation of the Khakass folklore, by collecting and publishing his works. The information on the Khakass wedding, the forms of marriage, the custom of avoiding has a particular value (Samples of folk literature of the Turkic tribes in 1907). The materials of the expedition to Tuva (old name Soyotia) in 1902-1903 of F.Y. Kon were published in 1934 (Kon 1934). E.V. Yakovlev described various aspects of the family life of the Khakas: the wedding, the position of a woman, divorce, inheritance (Yakovlev, 1900). However, in the works of the authors of the XVIII-XIX centuries family rituals did not receive separate coverage. 
The study continued in the Soviet period as well. In the 30s of the XX century S.A. Tokarev in his work "Pre-capitalist Remnants in Oyrotia", examining some aspects of life of the indigenous population of Gorny Altai before the revolution, noted the peculiarity of kinship among Altaians, a characteristic feature of the tribal divisions, the presence of strict exogamy (Tokarev, 1936).

N.P. Dyrenkova in her articles revealed the problem of the meaning of the remnants of the maternal kind, including the institute of avunculate among the Altaians. She described the relationship between the nephew and the uncle of mother's side in the form of reverence and mutual assistance (Dyrenkova, 1937).

Works of Yu.A. Shibaeva "Remnants of the Tribal System of the Khakas in the System of Kinship and Marital and Family Relations", "Remnants of the Matriarchal Epoch of the Khakas" contain Khakass material about the family, kalym, dowry, avunculate, sororate, levirate (Shibaeva, 1947, 1948).

Changes in the traditional rituals of the Altai people as a result of everyday contacts with the Russian population and the activities of the Christian church on the territory of Gorny Altai are covered in the monograph of EM. Toschakova "Traditional features of the folk culture of the Altaians (XIX - early XX centuries)" (Toschakova, 1978).

N.I. Shatinova in the monograph "Family of the Altaians" noted that wedding ceremonies of the second half of the XX century were conducted in an incomplete form, due to the material capabilities of the population. First of all, the changes affected: matchmaking, belkenchek and the visit of the newly married couple of the bride's parents (Shatinova, 1981).

Family ritual was briefly considered in the collective monograph "Family rituals of the peoples of Siberia", published in 1980

N.A. Tadina in the 1980-1990s conducted a comprehensive research of the traditional Altai wedding and its results were published in the monograph "Altai Wedding Rituals of the XIX - XX Centuries." In a traditional wedding ceremony she singled out matchmaking, pre-wedding preparation, the wedding itself and afterwedding activities (Tadina, 1995).

The authors of the collective monographs "The Traditional World Outlook of the Turks of Southern Siberia" $(1989,1990,1991)$ partly touched upon the topic "The Bride in the Context of the Binary Opposition of the "kin" - "alien"'. In the same period, studies on family rituals and Khakass scholars characterizing various forms of marriage were published: K.M. Patachakov "Family-kinship Relations Among the Khakas" (Patachakov, 1981), V.Ya. Butanaev "Wedding Ceremonies of the Khakas in the late XIX - early XX century" (Butanaev, 1987), Yu.G."Kustova Traditional Naming of the Khakas" (Kustova, 1995).

L.I. Sherstova considers family relations in the context of the study of burkhanism as the national-religious ideology of Altai-kizhi in "Burkhanism: the Origins of Ethnicity and Religion" (Sherstova, 2010).

A number of works related to the rituals of the life cycle of the Turks of the Sayan-Altai area has appeared since the 2000s. V.A. Kleshev in the monograph "Popular Altaian Religion: Yesterday, Today" notes that the family rituals of the southern Altaians now ADAYS, despite the influence of the "Soviet norms", have retained some traditional ideas and prohibitions (Kleshev, 2011).

Monograph of N.O. Tadysheva "The influence of Christianization on the Family Rituals of the Indigenous Population of Gorny Altai" is aimed at identifying temporary changes and territorial characteristics of family rituals under the influence of Orthodoxy (Tadysheva, 2011). 
The Tuvinian wedding ritual is reflected in the research of M.B. Kenin-Lopsan "Myths of Tuvinian Shamans", "Traditional Culture of Tuvinians", which reveals family rituals as part of the traditional picture of the world of Tuvinians (KeninLopsan, 2002, 2006). In the monograph of S.Ch. Dongak "Traditions of Tuvinian Wedding" marked ethical norms and behavioral aspects of pre-wedding and wedding ceremonies (Dongak, 2012). In the study S.M. Biche-ool "Traditional Marriage and Family Relations Among Tuvinians and Their Transformation During the Soviet Period" considered wedding rituals, their sequence, as well as kinship terms, forms of marriage prohibition (Biche-ool, 2018) as well as in the articles of S.M. Biche-ool "Tuvinian Wedding Ceremony - Dugdeeshkin" (Biche-ool, 2003), Zh.M. Yusha "Wedding Rites of Tuvinians: Traditions and Innovations", "Wedding rites of Tuvinians" (Yusha, 2008), Hertek L.K. "The image of "Askak-Kadai" - "LameOld Woman" in the traditional wedding rituals of Tuvinians".

Research of V.Ya. Butanaev are devoted to the traditional life of the Khakass family and are reflected in the monographs "Peculiarities of Culture and Life of the Turks of the Sayan-Altai" (Butanayev, 2011) and "Everyday and Holidays of the Turks of Khongorai", which comprehensively describes family life and the festive culture of the Khakas of the XIX-XX centuries. (Butanaev, 2014)

Studies on customary family law of E.V. Enchinova and Medvedeva T.N. describe the transformation of the customary family law of the Altaians and the Khakas on the example of the customs of the life cycle. Legal practices related to family rituals regulate the cycle of the emerging rights and obligations of family and kind members (Yenchinov, 2013; Medvedeva, 2014).

Analysis of the review of published literature suggests that most aspects of the problem under consideration did not become the object of special study. They were dealt with only in connection with the study of other issues of Siberian ethnography on family rituals, in particular within the framework of wedding ceremonies. The published material is scattered across numerous historical and ethnographic works, which makes it difficult to search for it and ultimately makes it difficult to create a holistic view of its modern specific features. It seems that this study will help fill the existing gap in the ethnography of the Sayan-Alta iTurks.

Results. Family ritual is one of the conservative areas of traditional culture. The rite of marriage is combined in its content with other transitional rites of the family cycle, but has its own specifics: wedding ritual is associated with a change in the social status of a person, unlike maternity and funeral rites, primarily determined by natural and biological factors.

In the process of the wedding ceremony, the former social and kinship relations are rebuilt, first of all it concerns the bride. Violation of the social status of the bride in the intermediate phase of the ceremonial "transition" created a danger for her in terms of communication with others, especially with people in a similar critical situation. Apparently, this is connected with the prohibition for two sisters to marry at the same time. The weakening of the bride's social ties before finalizing the marriage this transitional period brings her closer to death, which is manifested in the bride's isolation in the prohibition to touch her, look at her, in her silence, motionlessness, separation from the outside world and covering the bride's face with a veil.

As the researchers of the traditional picture of the world of the Turkic peoples of Siberia note, female maturity took place in her husband's house, in a "foreign space", and the relocation to this space was carried out by ritual abduction. Ways of moving a girl to a foreign territory were arranged in the same way as an epic hero or a shaman crossed the border of another world. She was kind of sleepy or dead, she was wrapped, closed, and "kidnapping" mostlytook place in the evening or at night 
(Lvova EL, Oktyabrskaya IV, Sagalaev AM, Usmanova MS, 1988: 76). In particular, among the Altai people in the past, when the girl was kidnapped, she was wrapped in a felt carpet and was carried away without showing anyone. One of the meanings is that the girl being pulled away from her family deities, parents, defenders of the terrain was kidnapped. Therefore, the girl was taken away at night so that no one could notice it. And the fact that the girl was wrapped and carried away symbolizes her "death" in the place where she was born, grew up, so her life ends. Her guards must let her go. And after all the wedding actions are performed, she would be born again in a new status, in a new place" (Ukachina, 2012: 16, trans. N.O. Tadysheva).

In traditional ideas, the bride, especially in the crucial period of the ritual "transition", is endowed with features of sacredness. When the girl is taken away from her parents, she comes out of protection. She is surrounded by evil forces. Therefore, she must be protected. The groom's family must take the girl's soul koot from her parents' house. In this regard, it is necessary to arrange matchmaking kudalaar without delaying (Ukachina, 2012: 17, trans. N.O. Tadysheva). The bride in this transitional period has demonic properties that bring her closer to the mythological character. At the moment of the loss of the former social ties and still unsettled new ones, the bride comes into close contact with the other world. The perception of the bride as an "unclean person" during this transitional period is strong. In the marriage ritual, ideas about the "kin-alien" category and belief in negative influence from the "someone else" are strong. In the family ritual, successive ceremonies are held that accompany the transition of the future spouses from one state to another, from the "alien" world - to "their own". Initially, the bride Kelinappears as a "stranger", "alien." Her "dangerous" influence against her new relatives is strong, and measures of magical and religious protection are taken against her. As a result of the ritual there is a "separation" from the family of the parents, from the old home cult and gradual incorporation into the new environment

Altaians as well as Tuvinians and Khakas go three times around the yurt of the newlyweds by the sun during the wedding ceremony. Although some studies suggest that this ritual is forgotten (Yusha, 2008: 52). The Tuvinian wedding should take place in a new newlyweds' yurt. According to the tradition all participants in a wedding celebration should travel around the new yurt by the sun, which means expressing the best wishes and blessings to the newlyweds. If there was no enough time to set a new yurt, the same detour is made around the support pole of the future yurt (Kenin-Lopsan, 2006: 28).

In some areas of the Altai Republic, the bride, accompanied by other daughtersin-law and other relatives, coming up to the aiyl where the wedding is taking place, should walk around it a certain number of times. Different places indicate different number from two to four, but it must necessarily be an even number (Tadysheva, 2011: 119).

Someone from the groom's side pours fermented milk diluted with water into a bucket and sprinkles it onto the clothes of the present just for laughs. According to researchers, this is a fun cleansing. In the Altai wedding rituals, such a ritual of purification is also celebrated. Thus, in 1955 it was recorded, "Many elements of the former wedding ritual, which had a definite symbolic meaning, such as pouring milk on a bride, tying her eyes, can now be perceived as offensive, and they are not performed any more" (ON SRI.FM. Case number 3. Record, Kalanakov, 1955: 6).

Among the Altai people one of the obligatory rites of the wedding ceremony is the custom to cover the bride's face with közhögö - wedding curtain, the Khakas people did it with headscarf tied in a special way (Butanaev, 2014: 205), Tuvinians used a wedding veil named tumalai/dumaalai (Kon, 2002: 105, Yakovlev, 2002: 58). 
Until all the rites of transition of a new member into the family were held, she was still "alien" and "dangerous". Therefore, it was necessary to cover up the young girl until of her ritual transition into her husband's family and home is completed.

In the Altai tradition the groom did not go to pick up the bride on the wedding day, but daughters-in-law - jere and nephews - jeeni (on the maternal line) did it instead. This custom is probably also aimed at protecting the groom and his family from "strangers", because the procession involves women and nephews of another kinship. This reflected the significance of the maternal kinship concept, because basically they tried to marry the girls of mother's kind, so groom'sjeeni and the bride, and maybe the groom's jerreler were of the same kind. Researchers associate the groom's nephews, younger brother or close younger relative, who are sent for the bride, with the custom of the levirate (Butanaev, 1987: 187) or the echo of the group marriage (Butanaev, 2011: 69). But in our opinion, this custom emphasizes the preservation of matrilocalism norms in the Altai family rituals. It is obvious that the ceremonial actions performed around the bride are aimed atneutralizing her or minimizing the danger coming from her.

The Khakass also recorded that the right of the first contact with the bride before the rites of her transition to the status of wife had only daughters-in-law. So, at the wedding an aunt (the wife of the husband's elder brother) covers the bride with a cloth without showing her face to anybody (Samples, 351).

In the Tuvinian wedding rituals Askak-Kadai (lit. Lame Old Woman) is an obligatory person, one of the main characters at the stage of the bride's entry into the family (kind) of the groom. When the bride and her relatives drive up to the groom's camp one of male relatives of the bride portrays Askak-Kadai, while limping he holds an ax in his hands or a bucket in some cases. The bride covered with the tumalai/dumaalai follows him, holding on to his hem. Asakak-Kadai, limping, passes to the groom's parents' yurt, opens the canopy and passes the cup of milk over the threshold. In some cases, the exchange of the bowl with milk is held outside the entrance to the yurt (Hertek).

According to other sources, one of the features of the Tuvinian wedding is the blessing of the bride. For the uttering of the blessing, the most respected and kind woman is chosen and she is assigned a fictional name Askak-Kadai, which literally means from Tuvinian the "Lame Woman". Before the blessing she comes to the wedding with a bag of millet and a small ax. Askak-Kadai scatters raw millet and walks between yurts, easily striking the ground with an ax in some places. And the bride, holding on to the flap of her robe, follows her. A bag with millet and an ax is left by the woman in the last yurt (Kenin-Lopsan, 2006: 30). The Tuvinianbride should sit on the bed. The most decent and respected woman cares about the girl. When the bride leaves the yurt, the woman follows her, accompanies her everywhere, and follows her like a shadow. The bride carefully hides her face, so she covers her head with a wedding blanket. A curtain is placed in front of the bed where the bride is sitting so that people cannot see her face. The groom should not enter the new yurt until the stars appear in the night sky. And only with the advent of stars, he can go into the yurt to his bride (ibid.).

Braiding the bride's hair. At the Altai wedding, the daughters-in-law (both from the bride's and groom's sides) performed the ceremony of braiding the bride's hair. The girl's hair was divided precisely in the middle of the head in two braids. They braided the hair, smearing it with milk and melted butter. (Tadysheva, 2011: 119). The ceremony of braiding hair symbolized not only the transition of the bride to the status of a married woman, but also emphasized her essential change. Of course, the transition of a girl from one family to another comes to the fore, but the origins of 
the ritual lie much deeper, and this ritual can be characterized as kind of magical. The idea of the power supposedly contained in the hair is universal. Loose hair endues its owner even with more power or strengthen her connection with the sacred world. By letting down the bride's hair, they released the devastating chaos, symbolized by "untidy head", in order to defeat him again. Combing hair meant restoration of the ordered proportionality of appearance of the person and, therefore, a world order. Due to the magical rite of protection, two braids of a married woman finally turned her from "theirs" into "ours" (Sherstova, 2008: 188).

According to the Tuvininan custom, after the matchmaking of a girl, they braided another braid - "SaiChash". Before marriage she could wear one or two braids. An additional braid was plaited by a relative from the mother's side who had a prosperous family life. The additional braid testified that its owner is already engaged. (Yusha).

At the end of the XIX century in Khakassia, when a girl by a prior arrangement was brought to the groom's house, a similar ceremony was performed. The bride's hair was let down by the groom's aunt (daughter-in-law-T.N.) and braided in two women's braids. Then a small feast called "hair feast" was arranged (Samples, 350). Later during the Khakassian wedding celebration "sastoi" took place(lit. feast of hair), during which a sponsor mother - "pazyrtkhanidzhe" (usually the groom's eldest daughter-in-law) together with her sister-in-law really let down the bride's hair and made two braids (Butanaev, 2014: 204).

The reflection in the oral folklore of this rite of transition indicates its meaning in the traditional picture of the world, as in the Khkass epic "Ai-Khuuchin":

Sixty good braids

Alyp-Khan-Khys unbraided,

Two nice female braids

Women made for her.

Fifty good surmeses,

The children of the people and tribe, unbraided

Good crinkly braids

Separating and twisting, women plaited the strands for her (Ai-Huuchin, 1997: 161).

In the Altai epic:

Kumyuzek-Aruabakay had

Beautiful [like pearls] hair eight kelins,

Combed on both sides.

"Your long beautiful hair,

Was it combed, Kumyuzek-Aru?

A friend to go through life together

Have you found, Kumyuzek-Aru?

Precious as pearls is your hair

Was it plaited [in two braids], Kumyuzhek-Aru?

A beloved friend

Have you found, Kumyuzek-Aru?"(Alyp-Manash, 2011: 115,117).

One of the etiquettes of the behavior of the Altaians is kaiyndas- a custom of avoidance by the bride of the senior relatives of her husband, and their avoidance is called kelindesh. The bride is first of all the representative of a different kind, and, even if married, doesn't lose this belonging. The bride had to observe the following set of prohibitions: pronouncing the name, improper appearence (in the presence of elder relatives of her husband kainy she can't bare her arms above the wrist, to show bare legs, to bare breasts to feed the child), the visualization (not to appear with her head uncovered - he can't see her hair), space restrictions (in thekainy'saiyl 
she had to deal with the hearth carefully, that is not to step over the head of the fire, outside the aiyl she mustn't pass between the hitching post and kainy'saiyl), the ban on private meetings. She was life-long forbidden to call her husband's parents by names, nor to use the names of her husband's senior relatives both in their presence or absence. Even the names of objects, consonant with their names, the bride had to replace with other words in a conversation. Mainly, the bride changed the names of her parents-in-law. The bride was also forbidden to call by names the deceased ancestors of her husband. The idea of the magical meaning of the word is preserved, which, when pronounced by an "alien", in this case by an alien kelin, can be dangerous both for the husband and his relatives and can cause them harm. It caused the prohibition of direct addressing to them.

Among the Altaians there is a legend about a "Dumb bride," She called the a river - the murmuring, a tree - the burning, a wolf - the howling, a sheep - the bleating (Ukachina, 1984: 13). Informants also tell life situations, "The daughter-inlaw came to parents of her husband and said - there across the murmuring, near the burning the howling seized the bleating, and the long-tailed wasn't around. Her parents didn't understand what she was talking about." And the daughter-in-law used instead of taboo words their characteristics, "Across the river near the tree a wolf seized the lamb, and the dog wasn't around".

In the Khakass epic a bride doesn't call her husband's sister by name, when addressing to her:

Khan-Hys, worthy lady,

Addressing to Hys-Khan, says,

"The elder sister of Khan-Mirgen,

I have one word..." (Ai-Huuchin, 1997: 181).

In the Tuvinian epic "Boktug-Kirish, Bora-Shelei" father-in-law is instructing his daughter-in-law:

Once Khan sent for his daughter-in-law.

"Today, daughter, you will go to graze the sheep.

As for [words] you shouldn't say -

You don't say "rock", and don't say " river", and don't say "larch",

And don't say "wolf", don't say "raven," and don't say "eyes".

And don't say "peck", and don't say "ate",

And don't say "sheep" - he said.

And he sent her to graze the sheep.

In the evening she returned,

Mother-in-law entered the yurt.

Han says:

'Daughter, are the sheep that you have grazed all safe?"

Bora-Shelei replies:

"Not safe.

Under the grown in front of the rock

On the bank of the flowing

One of my bleating two howling

Took away, killed,

And two yelling black

Poked two looking of my bleating", she says indirectly (Boktug-Kirish, BoraShelei, 1997: 459).

It is also necessary to dwell on the ritual with a bowl of milk which takes place after the ritual of braiding the bride's hair, after the wedding curtain közhögökelingesüturar was opened. According to researchers, the mother-in-law 
expressed her recognition of the future daughter-in-law (Tadina, 1995: 85). After the bride steps over the threshold of her husband's yurt or her husband's parents, the Tuvinians also give her milk. Askak-Kadai brings the bride to the yurt of the groom's parents to utter a blessing to her. The mistress of the yurt pours milk into a drinking bowl, first she sips it, then gives the bowl to the bride with both hands. The bride should take a sip, and then pass the bowl with milk back to her mother-in-law with both hands. This ceremony means that their acquaintance took place and they can already communicate as close ones. The blessing of the bride takes place in the yurt of the groom's parents and occupies a higher, special place, wedding ceremonies (Kenin-Lopsan, 2006: 32).

Apparently, it is beyond a gesture of approval, in this ritual the sacredness of milk and the idea of it as a talisman comes to the fore:

Seeing her children to come,

Barbaa-Bagay was glad.

She welcomed and greeted

The sweet [girl] that her son took [to wife].

Treating with white milk,

On a white shirdek she asked them to sit down.

She cooked the best of food,

And treated her kin and kind (YoskyusUul, 2018: 821).

The conceptions about the cult of the mountains, which reflect the sacredness of the sacred ancestral mountain Ayyuk Tuu, are also preserved. In shamanism, Eesi Mountains is the patron saint of the clan family söök and family. The cult of ancestral mountains is closely connected with the cult of the ancestral territory. The cult of honoring the mountains has been existing among the Altaians since the ancient times. Many sacred peaks are denominated by the terms yiyik (consecrated), recorded as early as in ancient Turkic inscriptions. Archaic beliefs and customs associated with the cult of the mountains apply to all the sacred mountains. They were considered forbidden for hunting, harvesting firewood, grazing livestock. The daughters of another kind could not climb the tribal mountain:

The range of Kirim-son is standing behind aal

For the brides was a forbidden mountain (Ai-Huuchin, 1997: 355).

After carrying out all the rites of passage, the daughter-in-law as the hostess prepared tea and served treats to the guests. So in 1955 in Altai it was recorded that after the bash öpÿ (braiding of hair) the daughter-in-law was treating those present with tea [SA RIA. FM Case number 3 Kalanakov A. and Altaian wedding rite of "toi" based on materials from a trip to Ust-Kanskyaymak, October 1955. C.11-12]. Nowadays in Kosh-Agach district of the Altai Republic after the rites of braiding hair, opening wedding curtains, the daughter-in-law sprinkles fire in aiyl of her father-inlaw, conducting a ritual of worshiping fire. The groom stands by her side. The bride prepares and treats everyone. The groom's mother gives the bride a bucket-bort wishing her to milk a cow, to live in prosperity, as well as she gives clothing and fabric (SA RIA. MSE. Case No. 119, diary entry 2017, informant Maykhieva LM).

In Tuva, according to the advice of the mother given to her daughter in advance, the bride cooks tea with milk, prepares all kinds of dishes, mostly brought from her parents' yurt, then she politely invites her father-in-law and her mother-in-law for tea. All the neighbours and relatives of her husband are invited together with them. So parents, relatives and neighbours of the groom will find out what their daughter-inlaw, and now his son's wife, is capable of. They learnt the girl's skill by the way she made tea. Parents and relatives of her husband evaluated the tea, brewed by her for the first time. That tea was supposed to create the glory of the young family. During 
the tea party in the new yurt, the people talked in a cheerful and easy manner, expressing admiration that the young mistress has prepared everything so well. Once again, they express the kindest wishes to the newlyweds (Kenin-Loops, 2006: 32).

The ritual "enesin ircüdinir kargyzhy" (literally, curse of mother's milk) in Altaians, "sütagy" (lit. white milk) or "emdj ackagy" (lit.white breasts), "emig kargyzhy "in Khakasia is considered to be relict, it takes place during a wedding trip to the bride's parents. The essence of this ceremony is that the bride's mother is given a symbolic payment by matchmakers for the mother's breast milk, for raising her daughter.

In Tuva, after some time, a young couple should visit the parents and relatives of the bride. Relatives give them mostly cattle: cows, horses, sheep, goats, young animals. The mother of the Tuvinian bride received a dairy cattle - a refund of milk that her daughter drank from her breast (Kon 2003: 104, Yakovlev 2003: 58).

In Altai, according to custom, a year later, newlyweds came to visit the bride's parents and the "enesin ircüdinir kargyzhy" rite was held. Now this ceremony is carried out immediately during belkenchek (literally the back of the animal's carcass, here is a wedding visit the next day after the wedding, the relatives of the bride's parents as a sign of respect for raising their daughter through offerings; rituals ayl datyr gany ("guest"), which takes place in two houses. It is important that there is an even number of dwellings (Tadysheva, 2011: 122).

The Khakas rituals were held during the time of the tirgin (törgin - a trip of the parents and relatives of the groom to the parents of the bride with wine and food, usually to receive a dowry) (Butanaev, 2014: 66-69).

Conclusion. Wedding ritual is a stable form due to its importance in traditional culture. The wedding ceremony does not exist separately from the system of ideas, from the model of the world accepted in society; it is a program that simulates human behavior, the actions of the man are dictated by the ideology adopted in this society. The main content and meaning of the blessing of the bride and groom during their wedding is that all who are present express their best wishes to the newlyweds in their life together to have happiness, many children, joys, which are based on peace and harmony between a man and a woman, their courage in overcoming all the difficulties that may occur on their way of life.

In the marriage ritual ideas about the "kin"-"alien" category and about belief in negative influence from the "alien" are strong. In the family ritual, successive ceremonies are held to accompany the transition of the future spouses from one state to another, from the "alien" world - to "their own" one. The common elements of the wedding ceremony of the Altaians, Tuvinians and Khakas, based on the binary opposition of "alien-kin" in relation to the daughter-in-law: face covering, hair braiding, the custom of avoiding are revealed.

\section{Әдебиеттертізімі / Список литературы}

1. Ай-Хуучин, 1997 - Ай-Хуучин / Хакасский героический эпос / Запись и подгот. Текста, пер., вступ. ст., примеч. и коммент., прил. В.Е. Майногашевой. - Новосибирск: Наука. Сибирское издательско-полиграфическое и книготорговое предприятие РАН, 1997. - 479 с. - (Памятники фольклора народов Сибири и Дальнего Востока; Т. 16).

2. Алып-Манаш, 2011 - Алып-Манаш. Алтайский героический эпос. / Составление, перевод, комментарии 3.С. Казагачевой. - Горно-Алтайск: ОАО «Горно-Алтайская типография», 2011. - 128 с.

3. Боктуг-Кириш, Бора-Шэлей, 1997 - Боктуг-Кириш, Бора-Шэлей /Тувинские героические сказания / Сост. С.М. Орус-оол. - Новосибирск: Наука, 1997. - С. 298-527. (Памятники фольклора народов Сибири и Дальнего Востока; Т. 12). 
4. Бутанаев, 2014 - Бутанаев В.Я. Будни и праздники тюрков Хонгорая. - Абакан: ООО «Журналист», 2014. - 316 с.

5. Бутанаев, 2011 - Бутанаев В.Я. Особенности культуры и быта тюрков Саяно-Алтая. - Астана: Кантана Пресс, 2011. - 440 с.

6. Бутанаев, 1987 - Бутанаев В.Я. Свадебные обряды хакасов в конце XIX - начале XX в. // Традиционные обряды и искусство русского и коренных народов Сибири. - Новосибирск: изд-во «Наука» Сибирское отд., 1987. - С. 179-193.

7. Ёскюс уул, 2018 - Ёскюс уул. Ӧскӱс уул. // Алтай баатырлар (Алтайские богатыри). Т. III. Серии «Памятники эпического наследия Алтая». / Подготовка, переводы текстов, примечания к алтайским текстам, комментарии к русским переводам, составление словаря выполнены М.А. Демчиновой, 3.С. Казагачевой, А.А. Конуновым, К.В. Ядановой. Предисловие М.А. Демчиновой. - Горно-Алтайск: БНУ РА «Научно-исследовательский институт алтаистики им С.С. Суразакова», 2018. - С. 750-821.

8. Кенин-Лопсан, 2002 - Кенин-Лопсан М.Б. Мифы тувинских шаманов. - Кызыл: Новости Тувы, 2002. -544 c.

9. Кенин-Лопсан, 2006 - Кенин-Лопсан М.Б. Традиционная культура тувинцев. - Кызыл: Тувинское книжное издательство, 2006. - 232 с.

10. Кон, 2002 - Кон Ф. За пятьдесят лет // Традиционная культура тувинцев глазами иностранцев (конец XIX - начало XX века) - Кызыл: Тувинское книжное издательство, 2002. - С. 69-108.

11. Кон, 1934 - Кон Ф.Я. Экспедиция в Сойотию. За пятьдесят лет. (соч.) ч.ІІІ - Москва, 1934 - М.: Издательство всесоюзного общества политкаторжан и ссыльно-поселенцев, 1934. - 396с.: илл.

12. Кустова, 1995 - Ю.Г. Традиционное имянаречение у хакасов // Хакасия в XX веке: хозяйственное и социальное развитие. - Абакан, 1995. - С. 154-159.

13. Львова, Октябрьская, Сагалаев, Усманова, 1988 - Львова Э.Л., Октябрьская И.В., Сагалаев А.М., Усманова М.С. Традиционное мировоззрение тюрков Южной Сибири. Пространство и время. Вещный мир. / - Новосибирск: Наука. Сиб. отд-ние, 1988. - 225 с.

14. Медведева, 2014 - Медведева Т.Н. Обычное семейное право хакасов: Автореф. дис. канд. ист. наук. [Электронный ресурс] // Электрон.текст. дан. Электронная библиотека диссертаций dslib.net, 2007-2014. URL: dslib.net>etnografia...semejnoe-pravo-hakasov.html (дата обращения: 27.04.2014).

15. Монгуш, 2001 - Монгуш М.В. История буддизма в Туве (вторая половина VI - конец XX в.) Новосибирск: Наука, 2001. - 200 с.

16. НА НИИА - НА НИИА. МНЭ. Дело № 117, аудиозапись 2018 г. Тадышевой Н.О., информант Чилбакова (Калкина) Евгения Емельяновна, 1964 г.р., сёёккёбёк (сӧӧккӧбӧк), месторождения с. Паспарта Улаганского района, место проживания с. Беш-Озок Шебалинского района Республики Алтай 17. НА НИИА - НА НИИА. МНЭ. Дело № 119, дневниковая запись 2017 г. [стр. 1-5], информант Майхиева (Чичинова) Лилия Мамыевна. Состав экспедиционного отряда: Тадышева Н.О.

18. НА НИИА - НА НИИА. ФМ. Дело № 3, машинописный текст [стр. 15]. Запись Каланакова А.И. Свадебный обряд «той» у алтайцев. По материалам поездки в Усть-Канский аймак октябрь 1955 г.

19. Образцы - Образцы народной литературы тюркских племен. Часть IX. Наречия урянхайцев (сойотов), абаканских татар и карагасов. Репринт изд.- [Б.м.], [Б.г.] - 696 с.

20. Патачаков, 1981 - Патачаков К.М. Семейно-родственные отношения у хакасов // Вопросы этнографии Хакасии. - Абакан, 1981. - С. 82-100.

21. Сагалаев, Октябрьская, 1990 - Сагалаев А.М., Октябрьская И.В. Традиционное мировоззрение тюрков Южной Сибири. Знак и ритуал. - Новосибирск: Наука. Сиб. отд-ние, 1990. - 209 с.

22. Тадина, 1995 - Тадина Н.А. Алтайская свадебная обрядность (XIX-XXвв.). - Горно-Алтайск: Юч-Сюмер, 1995. - 207 с.

23. Тадышева, 2015 - Тадышева Н.О. Свадебная обрядность народов Саяно-Алтая: общее и особенное // Вестник Томского государственного университета. История. - 2015. - № 6(38). - С. 133-138.

24. Тадышева, 2011 - Тадышева Н.О. Влияние христианизации на семейную обрядность коренного населения Горного Алтая - Горно-Алтайск: ОАО «Горно-Алтайская типография», 2011. - 176 с.

25. Укачина, 2012 - Укачина К.Е. Алтай той (Алтайская свадьба) / НИИ алтаистики им. С.С. Суразакова. Редактор: М.А. Демчинова. - Горно-Алтайск: Горно-Алтайская типография, 2012. - 192 с.

26. Укачина, 1984 - Укачина К.Е. Алтайские народные загадки. - Горно-Алтайск: Горно-Алтайское отделение Алт. книж., изд-ва. - 1984. - 102 с.

27. Хертек-Хертек Л.К. Образ «Аскак-Кадай» - «Хромой-Старухи» в традиционной свадебной обрядности тувинцев. [Электронный ресурс] Электрон.текст. дан. Наука и фрилософия. URL: 
http://tomb-raider6.narod.ru/lib/kk/kultura_i_mentalitet_naselenija_s/obraz_askak-kadaj-hromojstaru.html (дата обращения: 31.05.2014).

28. Шатинова, 1981 - Шатинова Н.И. Семья у алтайцев. Горно-Алтайск: Горно-Алтайское отд. Алт. книжн. изд-ва, 1981. - 183 с.

29. Шерстова, 2008 - Шерстова Л.И. Представление о «чужих» в ментальной традиции аборигенов Южной Сибири // Народонаселение Сибири: стратегии и практики межкультурной коммуникации (XVII-начало XX вв.). - Новосибирск, 2008. - С. 186-246.

30. Шерстова, 2010 - Шерстова Л.И. Бурханизм: истоки этноса и религии / Отв. Ред. В.П. Зиновьев. - Томск: Томский государственный университет, 2010. - 228 с.

31. Юша, 2003 - Юша С.Ю. Свадебные обряды тувинцев [Электронный ресурс] Электрон. текст. дан. URL: http://2003.vernadsky.info ıworks/g4/03038.html (дата обращения: 30.05.2014).

32. Юша, 2008 - Юша Ж.М. Свадебная обрядность тувинцев: традиции и новации // Традиции и инновации в современном фольклоре народов Сибири. - Новосибирск, 2008. - С. 52-62.

33. Яковлев, 1900 - Яковлев Е.К. Этнографический обзор долины Южного Енисея. - Минусинск: Тип. В.И. Корнакова, 1900. - 357 с.

34.Яковлев, 2002 - Яковлев Е.К. Этнографический обзор инородческого населения долины южного Енисея и объяснительный каталог этнографического отдела музея // Традиционная культура тувинцев глазами иностранцев (конец XIX - начало XX века) - Кызыл: Тувинское книжное издательство, 2002. - С. 55-68.

\section{References*}

Aj-Huuchin, 1997 - Aj-Huuchin / Hakasskij geroicheskij epos / Zapis' i podgot. Teksta, per., vstup. st., primech. i komment., pril. V.E. Majnogashevoj. - Novosibirsk: Nauka. Sibirskoe izdatel'skopoligraficheskoe i knigotorgovoe predpriyatie RAN, 1997. - 479 s. - (Pamyatniki fol'klora narodov Sibiri i Dal'nego Vostoka; T. 16). [In Rus.]

Alyp-Manash, 2011 - Alyp-Manash. Altajskij geroicheskij epos. / Sostavlenie, perevod, kommentarii Z.S. Kazagachevoj. - Gorno-Altajsk: OAO «Gorno-Altajskaya tipografiya», 2011. 128 s. [In Rus.]

Boktug-Kirish, Bora-SHelej, 1997 - Boktug-Kirish, Bora-SHelej /Tuvinskie geroicheskie skazaniya / Sost. S.M. Orus-ool. - Novosibirsk: Nauka, 1997. - S. 298-527. (Pamyatniki fol'klora narodov Sibiri i Dal'nego Vostoka; T. 12). [In Rus.]

Butanaev, 2014 - Butanaev V.YA. Budni i prazdniki tyurkov Hongoraya. - Abakan: OOO «ZHurnalist», 2014. - 316 s. [In Rus.]

Butanaev, 2011 - Butanaev V.YA. Osobennosti kul'tury i byta tyurkov Sayano-Altaya. - Astana: Kantana Press, 2011. - 440 s. [In Rus.]

Butanaev, 1987 - Butanaev V.YA. Svadebnye obryady hakasov v konce XIX - nachale XX v. // Tradicionnye obryady $\mathrm{i}$ iskusstvo russkogo i korennyh narodov Sibiri. - Novosibirsk: izd-vo «Nauka» Sibirskoe otd., 1987. - S. 179-193. [In Rus.]

YOskyus uul, 2018 - YOskyus uul. Öskÿs uul. // Altaj baatyrlar (Altajskie bogatyri). T. III. Serii «Pamyatniki epicheskogo naslediya Altaya». / Podgotovka, perevody tekstov, primechaniya k altajskim tekstam, kommentarii $k$ russkim perevodam, sostavlenie slovarya vypolneny M.A. Demchinovoj, Z.S. Kazagachevoj, A.A. Konunovym, K.V. YAdanovoj. Predislovie M.A. Demchinovoj. - Gorno-Altajsk: BNU RA «Nauchno-issledovatel'skij institut altaistiki im S.S. Surazakova», 2018. - S. 750-821. [In Rus.]

Kenin-Lopsan, 2002 - Kenin-Lopsan M.B. Mify tuvinskih shamanov. - Kyzyl: Novosti Tuvy, 2002. - 544 s. [In Rus.]

Kenin-Lopsan, 2006 - Kenin-Lopsan M.B. Tradicionnaya kul'tura tuvincev. - Kyzyl: Tuvinskoe knizhnoe izdatel'stvo, 2006. - 232 s. [In Rus.]

Kon, 2002 - Kon F. Za pyat'desyat let // Tradicionnaya kul'tura tuvincev glazami inostrancev (konec XIX - nachalo HKH veka) - Kyzyl: Tuvinskoe knizhnoe izdatel'stvo, 2002. - S. 69-108. [In Rus.]

Kon, 1934 - Kon F.YA. Ekspediciya v Sojotiyu. Za pyat'desyat let. (soch.) ch.III - Moskva, 1934 M.: Izdatel'stvo vsesoyuznogo obshchestva politkatorzhan i ssyl'no-poselencev, 1934. 396s.: ill. [In Rus.]

*Contractions:

MSE - Materials of Scientific Expedidtions

SA RIA - Scientific Archive of the Research Institute of Altai studies n.a. S. S. Surazakov.

FM - Folklorematerials 
Kustova, 1995 - YU.G. Tradicionnoe imyanarechenie u hakasov // Hakasiya v HKH veke: hozyajstvennoe i social'noe razvitie. - Abakan, 1995. - S. 154-159. [In Rus.]

L'vova, Oktyabr'skaya, Sagalaev, Usmanova, 1988 - L'vova E.L., Oktyabr'skaya I.V., Sagalaev A.M., Usmanova M.S. Tradicionnoe mirovozzrenie tyurkov YUzhnoj Sibiri. Prostranstvo i vremya. Veshchnyj mir. / - Novosibirsk: Nauka. Sib. otd-nie, 1988. - 225 s. [In Rus.]

Medvedeva, 2014 - Medvedeva T.N. Obychnoe semejnoe pravo hakasov: Avtoref. dis. kand. ist. nauk. [Elektronnyj resurs] // Elektron.tekst. dan. Elektronnaya biblioteka dissertacij dslib.net, 2007-2014. URL: dslib.netıetnografia...semejnoe-pravo-hakasov.html (data obrashcheniya: 27.04.2014). [In Rus.]

Mongush, 2001 - Mongush M.V. Istoriya buddizma v Tuve (vtoraya polovina VI - konec HKH v.) Novosibirsk: Nauka, 2001. - 200 s. [In Rus.]

NA NIIA - NA NIIA. MNE. Delo № 117, audiozapis' 2018 g. Tadyshevoj N.O., informant CHilbakova (Kalkina) Evgeniya Emel'yanovna, 1964 g.r., syoyokkyobyok (söökköbök), mestorozhdeniya s. PaspartaUlaganskogo rajona, mesto prozhivaniya s. Besh-Ozok SHebalinskogo rajona Respubliki Altaj[In Rus.]

NA NIIA - NA NIIA. MNE. Delo № 119, dnevnikovaya zapis' 2017 g. [str. 1-5], informant Majhieva (CHichinova) Liliya Mamyevna. Sostav ekspedicionnogo otryada: Tadysheva N.O. [In Rus.]

NA NIIA - NA NIIA. FM. Delo № 3, mashinopisnyj tekst [str. 15]. Zapis' Kalanakova A.I. Svadebnyj obryad «toj» u altajcev. Po materialam poezdki v Ust'-Kanskij ajmak oktyabr' $1955 \mathrm{~g}$. [In Rus.]

Obrazcy - Obrazcy narodnoj literatury tyurkskih plemen. CHast' IX. Narechiya uryanhajcev (sojotov), abakanskih tatar i karagasov. Reprint izd.- [B.m.], [B.g.] - 696 s. [In Rus.]

Patachakov, 1981 - Patachakov K.M. Semejno-rodstvennye otnosheniya u hakasov // Voprosy etnografii Hakasii. - Abakan, 1981. - S. 82-100. [In Rus.]

Sagalaev, Oktyabr'skaya, 1990 - Sagalaev A.M., Oktyabr'skaya I.V. Tradicionnoe mirovozzrenie tyurkov YUzhnoj Sibiri. Znak i ritual. - Novosibirsk: Nauka. Sib. otd-nie, 1990. - 209 s. [In Rus.]

Tadina, 1995 - Tadina N.A. Altajskaya svadebnaya obryadnost' (XIX-XX vv.). - Gorno-Altajsk: YUchSyumer, 1995. - 207 s. [In Rus.]

Tadysheva, 2015 - Tadysheva N.O. Svadebnaya obryadnost' narodov Sayano-Altaya: obshchee i osobennoe // Vestnik Tomskogo gosudarstvennogo universiteta. Istoriya. - 2015. - № 6(38). - S. 133-138. [In Rus.]

Tadysheva, 2011 - Tadysheva N.O. Vliyanie hristianizacii na semejnuyu obryadnost' korennogo naseleniya Gornogo Altaya - Gorno-Altajsk: OAO «Gorno-Altajskaya tipografiya», 2011. - 176 s. [In Rus.]

Ukachina, 2012 - Ukachina K.E. Altaj toj (Altajskaya svad'ba) / NII altaistiki im. S.S. Surazakova. Redaktor: M.A. Demchinova. - Gorno-Altajsk: Gorno-Altajskaya tipografiya, 2012. - 192 s. [In Rus.]

Ukachina, 1984 - Ukachina K.E. Altajskie narodnye zagadki. - Gorno-Altajsk: Gorno-Altajskoe otdelenie Alt. knizh., izd-va. - 1984. - 102 s. [In Rus.]

Hertek-Hertek L.K. Obraz «Askak-Kadaj» - «Hromoj-Staruhi» v tradicionnoj svadebnoj obryadnosti tuvincev. [Elektronnyj resurs] Elektron.tekst. dan. Nauka i filosofiya. URL: http://tombraider6.narod.ru/lib/kk/kultura_i_mentalitet_naselenija_s/obraz_askak-kadaj-hromoj-staru.html (data obrashcheniya: 31.05.2014). [In Rus.]

SHatinova, 1981 - SHatinova N.I. Sem'ya u altajcev. Gorno-Altajsk: Gorno-Altajskoe otd. Alt. knizhn. izd-va, 1981. - 183 s. [In Rus.]

SHerstova, 2008 - SHerstova L.I. Predstavlenie o «chuzhih» v mental'noj tradicii aborigenov YUzhnoj Sibiri // Narodonaselenie Sibiri: strategii i praktiki mezhkul'turnoj kommunikacii (XVII-nachalo HKH vv.). - Novosibirsk, 2008. - S. 186-246. [In Rus.]

SHerstova, 2010 - SHerstova L.I. Burhanizm: istoki etnosa i religii / Otv. Red. V.P. Zinov'ev. - Tomsk: Tomskij gosudarstvennyj universitet, 2010. - 228 s. [In Rus.]

YUsha, 2003 - YUsha S.YU. Svadebnye obryady tuvincev [Elektronnyj resurs] Elektron.tekst. dan. URL: http://2003.vernadsky.info ıworks/g4/03038.html (data obrashcheniya: 30.05.2014). [In Rus.]

YUsha, 2008 - YUsha ZH.M. Svadebnaya obryadnost' tuvincev: tradicii i novacii // Tradicii i innovacii $v$ sovremennom fol'klore narodov Sibiri. - Novosibirsk, 2008. - S. 52-62. [In Rus.]

YAkovlev, 1900 - YAkovlev E.K. Etnograficheskij obzor doliny YUzhnogo Eniseya. -Minusinsk: Tip. V.I. Kornakova, 1900. - 357 s. [In Rus.]

YAkovlev, 2002 - YAkovlev E.K. Etnograficheskij obzor inorodcheskogo naseleniya doliny yuzhnogo Eniseya i ob"yasnitel'nyj katalog etnograficheskogo otdela muzeya // Tradicionnaya kul'tura tuvincev glazami inostrancev (konec XIX - nachalo HKH veka) - Kyzyl: Tuvinskoe knizhnoe izdatel'stvo, 2002. - S. 55-68. [In Rus.] 